\title{
CONSIDERATIONS OF IMPACT OF VENTURI EFFECT ON MESOPHILIC DIGESTION
}

\author{
ROZWAŻANIA NAD WPLYWEM EFEKTU VENTURIEGO \\ NA FERMENTACJĘ MEZOFILOWA
}

\begin{abstract}
Hydrodynamic cavitation caused by the Venturi effect is one of the most promising methods of sewage sludge pre-treatment. This study has been carried out to investigate the effect of hydrodynamic cavitation on disintegration of activated sludge foam and mesophilic fermentation. Cavitation was generated in standard Venturi tube with the diameter ratio $\beta=d_{0} / d_{1}=0.30$, working at $\sigma=0.249$. Detailed Computational Fluid Design (CFD) analysis in class of $k-\epsilon$ model of internal flow has been presented. Obtained analytical investigation results confirmed the effect of strong disruption of microorganism cells and release of free organic substance into the liquid phase. After a short (30 minutes) pre-treatment, chemical oxygen demand increased by 8.63 times while Müller's disintegration degree was $50 \%$. Moreover, undertaken mesophilic digestion trials brought significant improvement in biogas production.
\end{abstract}

Keywords: hydrodynamic cavitation, Venturi effect, activated sludge foam, mesophilic fermentation

\section{Introduction}

Anaerobic digestion is a common method for activated sludge stabilization resulting in the reduction of sludge volatile matter and the production of biogas. Anaerobic degradation of biomass and extracellular polymeric substances (EPS) is considered to follow a sequence of four phases: hydrolysis, acidogenesis, acetogenesis and methanogenesis. The slow degradation rate of activated sludge in the process of anaerobic digestion is due to the rate limiting step of sludge hydrolysis. Therefore, the pre-treatment of activated sludge by physical (thermal), chemical (eg pH adjustment, oxidation process using ozone or hydrogen peroxide), mechanical (hydrodynamic cavitation, ultrasonication), and biological (enzymes) methods can improve the subsequent anaerobic digestion [1-3]. Although the methods are

\footnotetext{
${ }^{1}$ Faculty of Materials, Civil and Environmental Engineering, University of Bielsko-Biala, ul. Willowa 2, 43-300 Bielsko-Biała, Poland

${ }^{2}$ Faculty of Mechanical Engineering and Computer Sciences, University of Bielsko-Biala, ul. Willowa 2, 43-300 Bielsko-Biała, Poland

*Corresponding author: kgrubel@ath.bielsko.pl
} 
different, the aim of all of them is partial or complete disintegration of bacteria cells, ie release of organic substances present inside of cells to the liquid phase.

Disintegration by hydrodynamic cavitation has a positive effect on the degree and rate of sludge anaerobic digestion [1, 4, 5]. Hydrodynamic cavitation causes formation of cavities (bubbles) filled with a vapour - gas mixture inside of the flowing liquid, or at the boundary of a constriction device due to a rapid local pressure drop. Subsequently, downstream the constriction (valve or nozzle) the pressure recovers causing cavities collapse. The collapse of the cavitation bubbles is defined as implosion and the forces associated with it result in mechanical and physicochemical effects. The physical effects include the production of shear forces and shock waves, whereas the chemical effects result into the generation of radicals eg formation of reactive hydrogen atoms and hydroxyl radicals, which can recombine to form hydrogen peroxide [6-8].

The new concept described in this work is based on combining hydrodynamic disintegration of activated sludge foam in order to improve anaerobic digestion process. The aim of carried out experiment on sludge digestion was to show the possibilities to improve and accelerate the anaerobic process.

\section{Methodology}

Hydrodynamic cavitation is the phenomenon based on vaporization of flowing liquid subjected locally to a sufficiently low pressure. Generally, it is a direct consequence of energy conservation:

$$
e_{k}+i+e_{p}+\Delta e=e_{t}
$$

in which total energy of liquid $\left(e_{t}\right)$ split to kinetic $\left(e_{k}=v^{2} / 2\right)$, enthalpy $(i=p / \rho+u)$, potential $\left(e_{p}=g \cdot z\right)$, and dissipated $(\Delta e)$ part $[9,10]$. When two locations in the stream are geometrically very close, differences of potential as same as internal energy can be neglected. As dissipated energy is always proportional to kinetic one, it brings direct coupling between two state variables of flow: pressure $(p)$ and velocity $(v)$. Figure 1 presents calculated axial velocity and static pressure profile of exemplary throttling device.

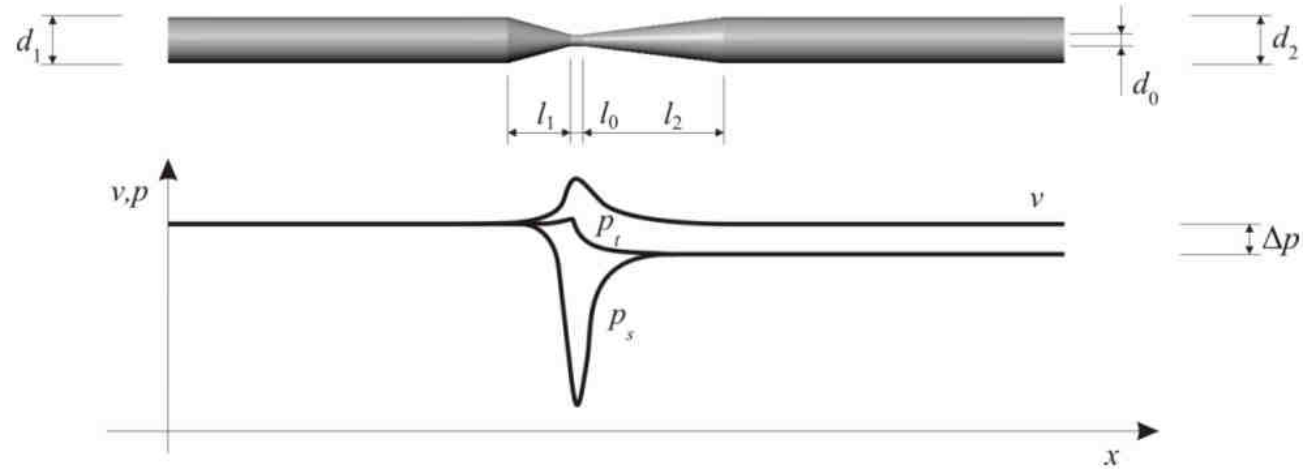

Fig. 1. Schematic drawing of throttling device in form of Venturi tube 
Whenever liquid passes through constriction velocities increases and simultaneously pressures decreases proportionally to the second power of velocity - strongly increasing the likelihood of cavitation occurrence.

\section{General concept and computational model of cavitating device}

Commonly used parameter to characterize flow potential to cavitate is a number of cavitation $(\sigma)$ [9-13]. This parameter was established on the assumption that total stagnation energy of liquid is $e_{t}=p_{\infty} / \rho$ in arbitrary stream cross section can be expressed as a sum $v^{2}{ }_{0} / 2+p_{0} / \rho$. Cavitational nucleation occurs - in elementary understanding and explanation when local pressure $p_{0}$, will be less or equal vapour pressure of the liquid $p_{v}$, in flow condition. On the contrary, if $p_{0} \geq p_{v}$ the difference $\Delta p=p_{0}-p_{v}$ reveals how far is phase transition or how much energy could be transformed to kinetic form:

$$
\frac{v_{0}^{2}}{2}+\underbrace{\chi \frac{v_{0}^{2}}{2}+\frac{p_{v}}{\rho}}_{p_{0} / \rho}=\frac{p_{\infty}}{\rho}
$$

Thus, by introduction $\sigma=(1+\chi)$ we have:

$$
\sigma=1+\chi=\frac{p_{\infty} p_{v}}{\frac{1}{2} \rho v_{0}^{2}} \approx \frac{p_{\infty}}{\frac{1}{2} \rho v_{0}^{2}}=\frac{\frac{p_{\infty}}{\rho}}{\frac{v_{0}^{2}}{2}}
$$

which forms necessary conditions for the appearance of cavitation:

$$
\chi \rightarrow 0 \text { or } \sigma \rightarrow 1
$$

In our research, an experimental set-up was supplied by worm pump with nominal discharge $q_{n}=0.139 \mathrm{dm}^{3} / \mathrm{s}$ and pressure $p_{n}=1.2 \mathrm{MPa}$. It was assumed that flowing liquid has density $\rho=999.7 \mathrm{~kg} \cdot \mathrm{m}^{-3}$ and viscosity $\eta=0.001308 \mathrm{~kg} \cdot \mathrm{m}^{-1} \mathrm{~s}^{-1}$ (equivalent of water at $10^{\circ} \mathrm{C}$ ). On the base of cavitation number concept, there can be identified cavitational regime of flow (Figure 2; relation $\sigma(\beta)$ is not continuous in form due to the technical limitations).

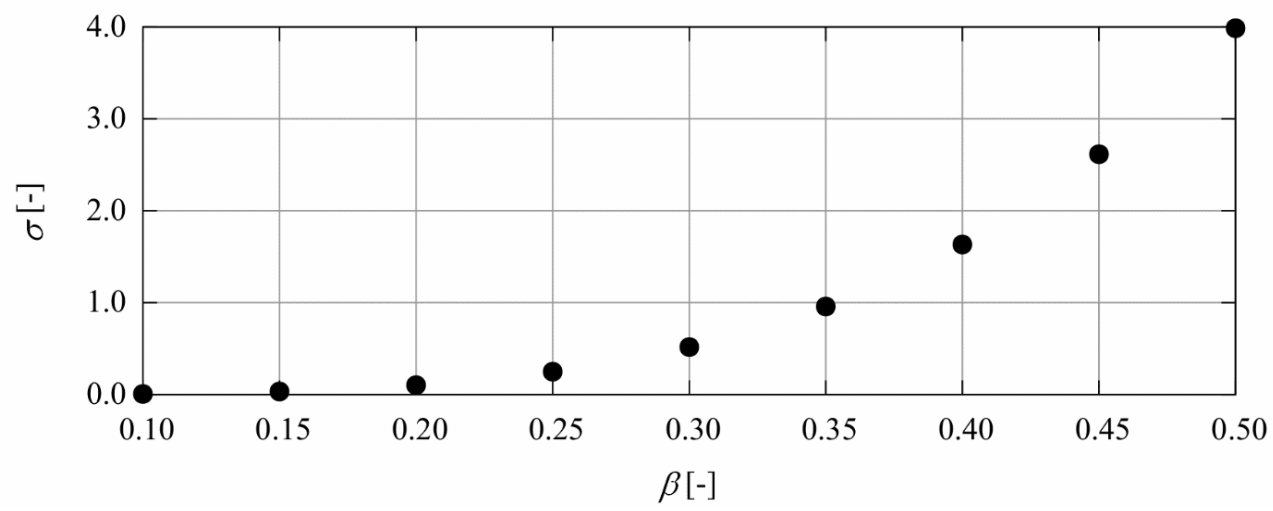

Fig. 2. Cavitation number $\sigma$ as a function of diameter ratio $\beta=d_{0} / d_{1}$ 
Therefore, cavitation should be expected for diameter ratios $\beta=d_{0} / d_{1}=0.30$, or less. Value $\beta=0.35$ makes limiting case when cavitation number is equal 0.957 . There was assumed somewhat lower value of ratio (0.25) which gives $\sigma=0.245$. Of course, cavitation number criterion helps to determine principal dimensions, however it does not settle geometric form of device.

The simplest way to obtain throttling effect is by creating a plate-shaped element with the orifice. However this kind of device provokes sludge deposits in the hydrodynamical shadow area, and from this practical reason, it was decided to use standard Venturi tube [13-16].

We have considered and tested several geometrical configurations. Figure 3 presents the final geometrical form of device and its finite element discretisation.

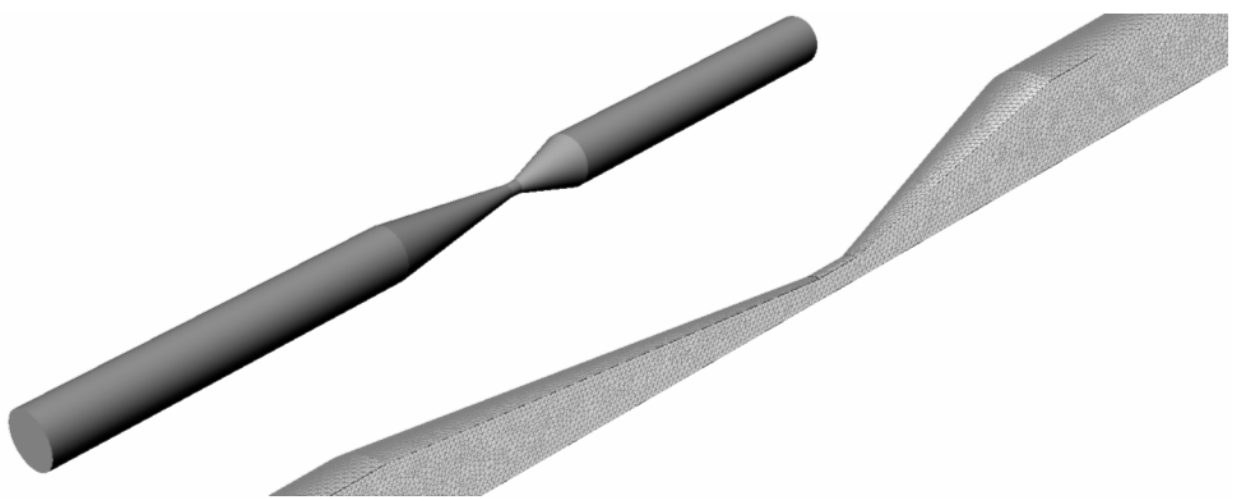

Fig. 3. Model of geometry and its discretisation (near throat part of mesh)

Geometry has been discretised into ten-nodded tetrahedral finite elements. Finial mesh contains $N=608938$ nodes and $E=403274$ finite elements. Chance of axial symmetry only a quarter of object geometry was discretised.

In selected flow condition, relationship between Reynolds number $\left(\operatorname{Re}_{0}=v_{0} \cdot d_{0} / v\right)$ and cavitation number $(\sigma)$ is shown in Figure 4.

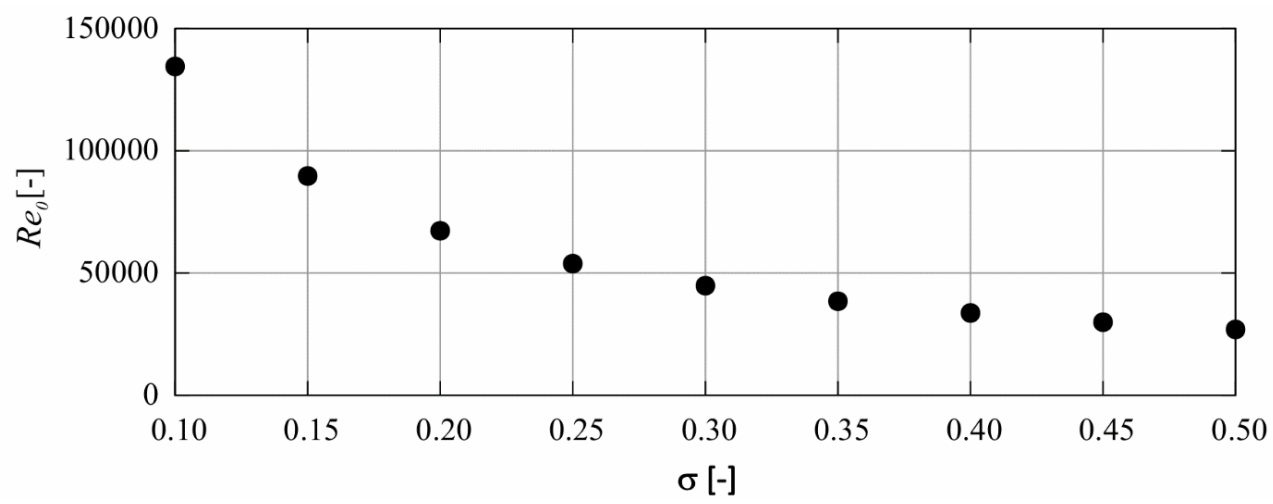

Fig. 4. Relationship between throat Reynolds number $\operatorname{Re}_{0}$ and cavitation number $\sigma$ 
These results suggest that flow becomes fully developed turbulent. Therefore, we decided to build computational model on a base of Reynolds averaged steady liquid mass and momentum balance equations $[17,19]$ :

$$
\frac{\partial \bar{v}_{i}}{\partial x_{i}}=0, \bar{v}_{j} \frac{\partial \bar{v}_{i}}{\partial x_{j}}=\frac{1}{\rho} \frac{\partial \bar{p}}{\partial x_{i}}+\frac{\partial}{\partial x_{j}}\left(\begin{array}{ll}
v \frac{\partial \bar{v}_{i}}{\partial x_{j}} & \overline{v_{i}^{\prime} v_{j}^{\prime}}
\end{array}\right) .
$$

Shear stresses in turbulent flow could be expressed by applying Boussinesq hypothesis:

$$
\frac{\partial}{\partial x_{j}}\left(v \frac{\partial \bar{v}_{i}}{\partial x_{j}} \quad \overline{v_{i}^{\prime} v_{j}^{\prime}}\right)=\left(v+v_{t}\right) \frac{\partial}{\partial x_{j}} \frac{\partial \bar{v}_{i}}{\partial x_{j}}=v_{e} \frac{\partial}{\partial x_{j}} \frac{\partial \bar{v}_{i}}{\partial x_{j}},
$$

as velocity gradients via eddy or turbulent $v_{t}$ viscosity coefficient $[17,19]$.

There are many concepts and theories involved in computational fluid dynamics how to relate this parameter to other flow variables. In considered here particular context most adequate and useful will be $k-\in$ model, in which eddy viscosity coefficient is calculated:

$$
v_{t}=c_{\mu} \frac{k^{2}}{\in}
$$

from kinetic turbulent energy $k=1 / 2 \overline{v_{i}^{\prime} v_{i}^{\prime}}$ and viscous dissipation rate of turbulent kinetic

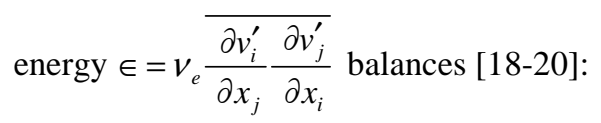

$$
\begin{gathered}
\bar{v}_{j} \frac{\partial k}{\partial x_{j}}=\frac{\partial}{\partial x_{j}}\left(\frac{v_{t}}{\sigma_{k}} \frac{\partial k}{\partial x_{j}}\right)+v_{t}\left(\frac{\partial \bar{v}_{i}}{\partial x_{j}}+\frac{\partial \bar{v}_{j}}{\partial x_{i}}\right) \in \\
\bar{v}_{j} \frac{\partial \in}{\partial x_{j}}=\frac{\partial}{\partial x_{j}}\left(\frac{v_{t}}{\sigma_{\in}} \frac{\partial \in}{\partial x_{j}}\right)+c_{1 \in} v_{t} \frac{\in}{k}\left(\frac{\partial \bar{v}_{i}}{\partial x_{j}}+\frac{\partial \bar{v}_{j}}{\partial x_{i}}\right) \frac{\partial \bar{v}_{i}}{\partial x_{j}} \quad c_{2 \in} \frac{\in^{2}}{k}
\end{gathered}
$$

Model boundary condition has been formulated as follows [18, 20-22]:

- constant and uniform velocity $v_{\text {in }}$ profile in the inlet cross-section, simultaneously local level of $k$, and $\in$ indirectly by setting turbulence intensity $\varepsilon$ and characteristic length scale $\lambda$

$$
k_{i n}=\frac{2}{3} \lambda^{2} v_{i n}^{2}, \in_{i n}=c_{\mu}^{3 / 4} \frac{k_{i n}^{3 / 2}}{\lambda}
$$

- $\quad$ no-slip adhesive boundary condition at channel walls;

- natural stress-free conditions on the upstream boundary, and zero value of reference pressure.

The five empirical constants of flow phenomenological model are given here the following values: $c_{\mu}=0.09, c_{1 \epsilon}=1.44, c_{2 \epsilon}=1.92, \sigma_{k}=1.0, \sigma_{\epsilon}=1.3$. 


\section{Methodology of experimental investigation of cavitational disintegration}

\section{Material}

Activated sludge foam samples were taken from a full scale municipal sewage treatment plant operated according to the EBNR (Enhanced Biological Nutrients Removal) process. The plant was designed for a flow of $120000 \mathrm{~m}^{3} / \mathrm{d}$. At present, the amount of treated wastewater is about $90000 \mathrm{~m}^{3} / \mathrm{d}$. Solid retention time (SRT) is about 14 days and concentration of MLSS $4320-4640 \mathrm{mg} / \mathrm{dm}^{3}$.

\section{The hydrodynamic disintegration}

Mechanical disintegration of a $25 \mathrm{dm}^{3}$ activated sludge foam samples was executed in the process of hydrodynamic cavitation. The experimental set up consisted of a 12 bar pressure pump, rating $0.56 \mathrm{kWh}$, output $500 \mathrm{dm}^{3} / \mathrm{h}$, which recirculated activated sludge foam samples from a container, through a $2.5 \mathrm{~mm}$ nozzle. Scheme of the experimental set-up is presented in Figure 5. Disintegration was carried out for 15, 30, 45, 60, and 90 minutes. The number of times the activated sludge foam passed through the nozzle is one time per three minutes.

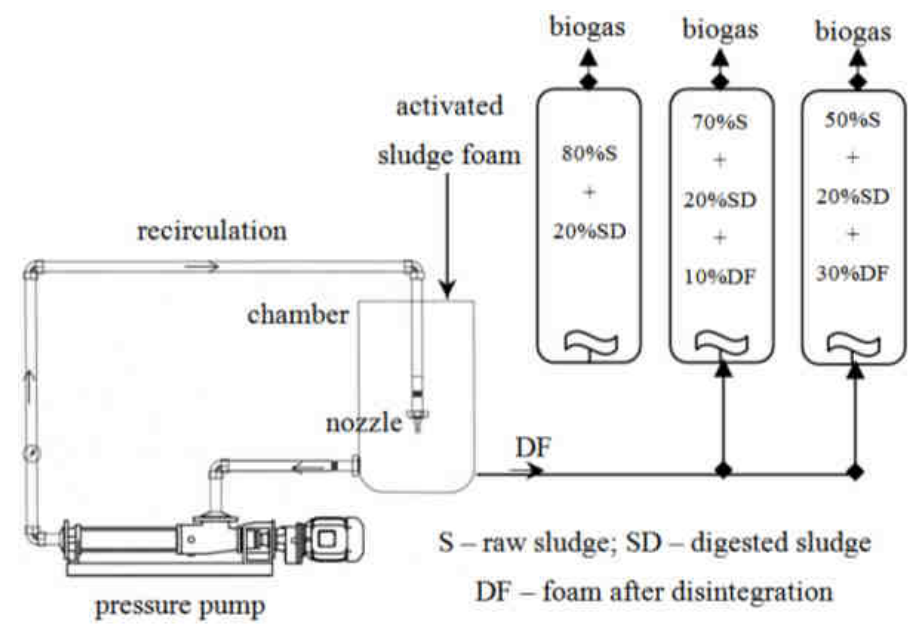

Fig. 5. Scheme of the experimental configuration

\section{The degree of disintegration}

In order to have a quantitative measure of the effects of disintegration, Müller [1] has proposed a coefficient, which is called the Degree of Disintegration $\left(\mathrm{DD}_{\mathrm{M}}\right)$. Here the $\mathrm{DD}_{\mathrm{M}}$ was determined according to the equation (11):

$$
\mathrm{DD}_{\mathrm{M}}=\left[\left(\mathrm{COD}_{1}-\mathrm{COD}_{2}\right) /\left(\mathrm{COD}_{3}-\mathrm{COD}_{2}\right)\right] \cdot 100[\%]
$$

where: $\mathrm{DD}_{\mathrm{M}}$ - degree of disintegration, $\mathrm{COD}_{1}$ is the $\mathrm{COD}$ (chemical oxygen demand) of the liquid phase of the disintegrated sample, $\mathrm{COD}_{2}$ is the $\mathrm{COD}$ of the original sample, and 
$\mathrm{COD}_{3}$ is the value after the chemical disintegration which was done by treating the foam samples for $10 \mathrm{~min}$ at $90^{\circ} \mathrm{C}$ after adding $\mathrm{NaOH}, 1 \mathrm{M}$, in ratio $1: 2$.

Centrifugation was done in all cases for $10 \mathrm{~min}$ with $30000 \mathrm{rpm}$.

\section{The fermentation experiments}

The anaerobic digestion experiments were performed in three glass fermenters $\left(25 \mathrm{dm}^{3}\right)$ operated in parallel at a temperature of $35 \pm 2^{\circ} \mathrm{C}$. Residence time was 22 days. The production of biogas was measured daily. Different rates of raw surplus activated sludge, digested sludge (inoculum), and disintegrated activated sludge foam have been applied:

- Fermenter 1 - was fed with raw surplus activated sludge (symbol: S; 80\% volume of fermenter), and digested sludge (SD; 20\% volume of fermenter), (as a control),

- Fermenter 2 - was fed with raw surplus activated sludge (symbol: S; 70\% volume of fermenter), digested sludge (SD; 20\% volume of fermenter), and activated sludge foam after hydrodynamic disintegration (symbol: DF; $10 \%$ of the volume),

- Fermenter 3 - was fed with raw surplus activated sludge (symbol: S; 50\% volume of fermenter), digested sludge (SD; 20\% volume of fermenter), and activated sludge foam after hydrodynamic disintegration (symbol: DF; $30 \%$ of volume).

Scheme of the experimental configuration is shown in Figure 5.

The aim of digested sludge (SD) added to the mixture was to bring the natural flora of fermentation microorganisms for the mesophilic conditions. The dose of SD has been optimized in previous studies in terms of minimizing the lag-phase and decreasing the disturbance of the fermentation process.

\section{Analytical methods}

COD was determined following the standard methods for the examination of water and wastewater, procedure 5220D [23]. COD was measured for samples before and after each time of disintegration. For colorimetric determinations of COD, a spectrophotometer Hach DR 5000 UV/VIS (HACH LANGE, Poland) was used. To analyse the soluble phase, the particulate sludge matter was removed by centrifugation $(10 \mathrm{~min}$ at $3000 \mathrm{rpm})$, and the resulting centrate was filtrated through $0.45 \mu \mathrm{m}$ pore size membrane filters.

\section{Results and discussions}

Our research of cavitational disintegration of activated sludge foam was concentrated on two aspects of the problem. First one and preliminary is dedicated to computational analysis of flow in throttling device. It has in view to gain information about flow fields evolution in the sense of appearance and spread of cavitational areas. At the next stage we try to assess how this physical phenomena affect foam biology.

\section{Evolution and assessment of cavitating device internal flows}

In the preliminary stage, we have performed series of numerical simulations throttling device internal flow. Figure 6 shows the velocity distribution in the throat region of the design. 


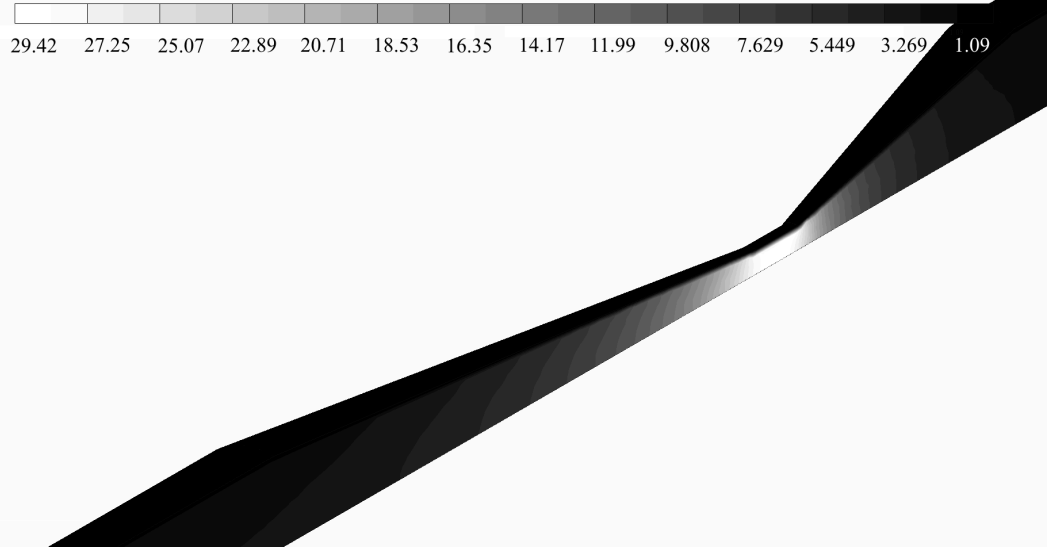

Fig. 6. Flow velocity distribution in throat region

Obtained here distribution of axial velocities has a form as shown in Figure 7.

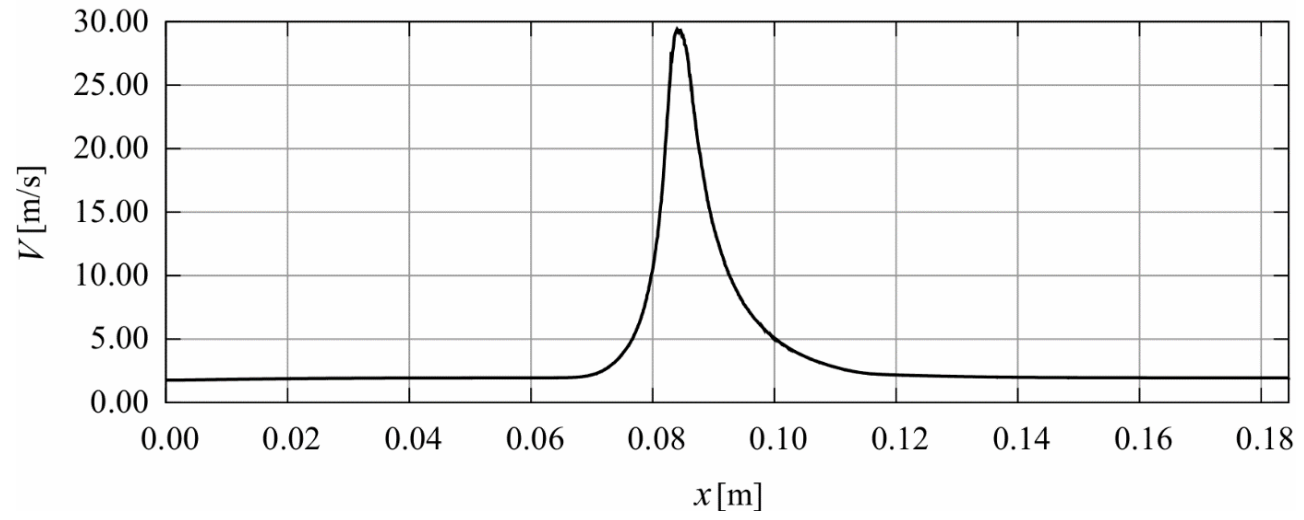

Fig. 7. Axial velocity distribution in throttling device

Flowing in liquid undergoes strong contraction effect in an inlet part of the device. Respectively to assumed diameter ratio $\beta=d_{0} / d_{1}=0.25$, velocity increases from 1.76 up to $29.40 \mathrm{~m} / \mathrm{s}$, it means that it increases by more than 16 times. Nevertheless, this value is kept only on the short length of throat. After leaving it, liquid enters into diffuser part of the device. Pressure recovery process starts, velocity slowly reduces but the static pressure increases. Because inlet and outlet diameter has the same value, accordingly to continuity equation, inlet and outlet velocities are equal. Changes in liquid velocities are reflected in pressures - Figure 8 presents obtained result for static and total pressure distributions. 


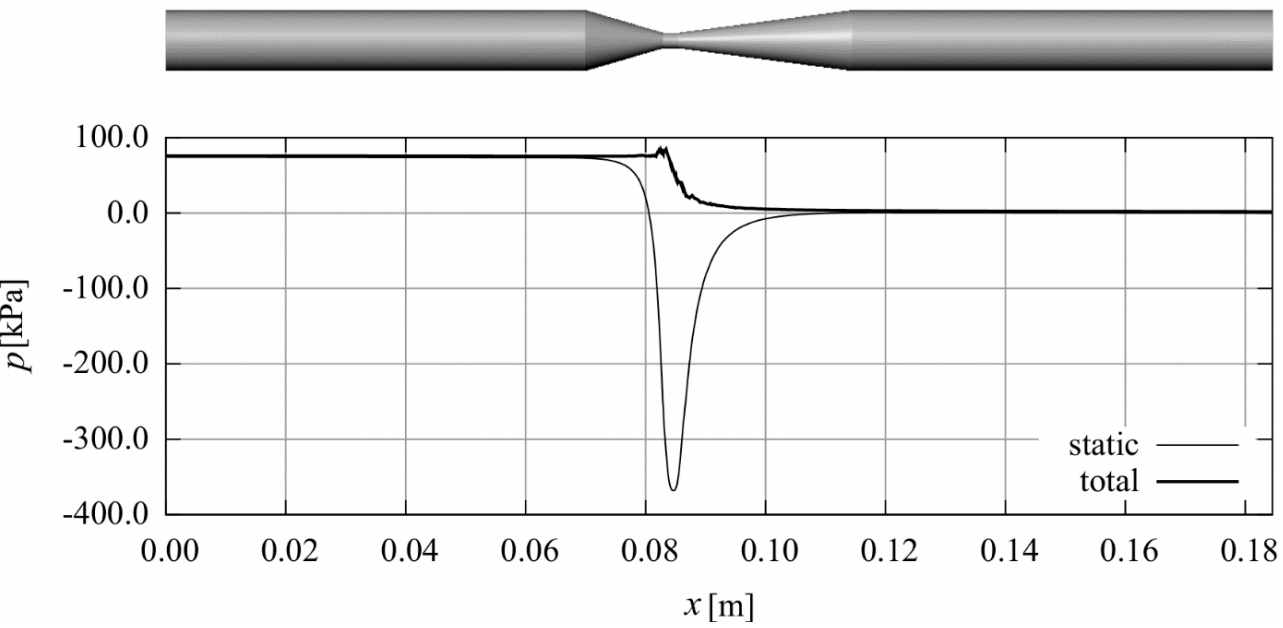

Fig. 8. Static and total axial pressure distribution

As usually, pressures are calculated from the flow equations up to some additive constant - to simplify - its value was set to zero. In this sense, plots presented in Figure 7 show changes of pressures but not absolute values. It could be interpreted as gauge or net pressure related to atmospheric.

Since outlet pressure is set to zero, entrance one is a direct measure of pressure $\Delta p$ and energy losses in considered device. From our calculation, $\Delta p=74.8 \mathrm{kPa}$. Starting from this value pressure decreases and reaches the minimum (net) value $-368.4 \mathrm{kPa}$, near $1.5 \mathrm{~mm}$ from entrance to the throat. After leaving this section, kinetic energy is in majority recovered in diffuser part. This shows other advantage of the throttling device, even in relation to screening type as orifice plate. Devices of that type, can provide the effect of pressure drop, but from a technical point of view, associated pressure losses should be as small as possible. Only well-shaped throttling type device can satisfy the last requirement.

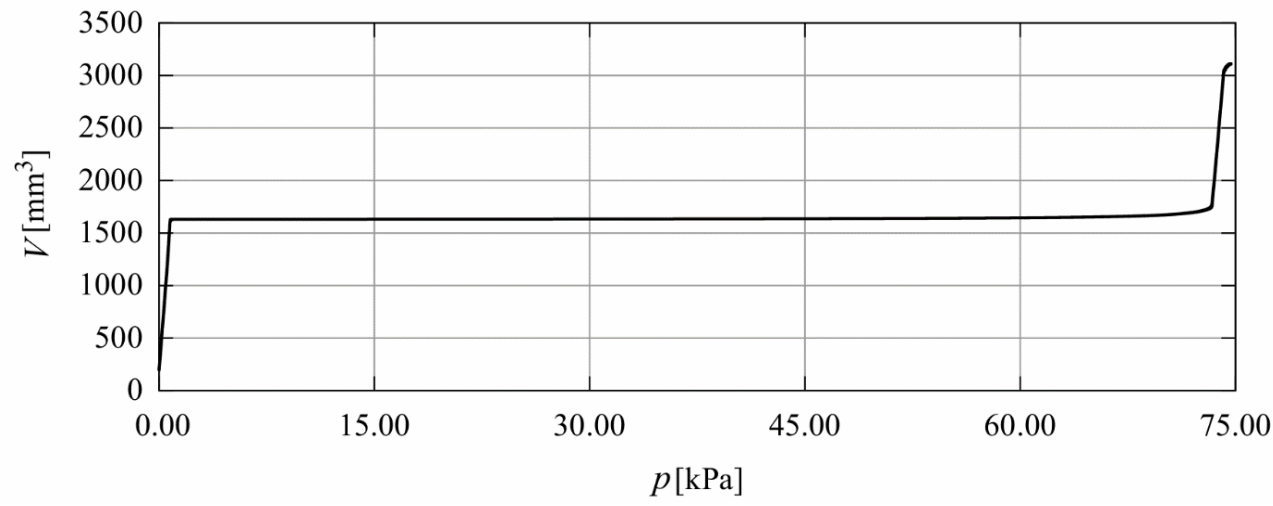

Fig. 9. Cumulative histogram of static pressure spread in liquid volume 
However, sufficiently small cavitation number or pressure does not guarantee of efficacious foam disintegration. In equal degree, size or spread of volume is also important. Figure 9 presents a histogram of distribution cumulative volume of liquid up to specific pressure. Averaged values are calculated over the volume of every finite element in the mesh. The total volume of liquid in the channel was 3110.74 cubic millimeters, while averaged volume of the finite element about 0.0077 cubic millimeters.

Over 52\% volume of liquid was under (net-) pressure less or equal than $1000 \mathrm{~Pa}$, whereas remaining part - 46\% - undergo pressures in the range of 72.760 to $74.789 \mathrm{kPa}$ mainly on the inlet cylindrical part of channel. Hence, we may expect that this kind of flow fields evolution provides very strong disintegrative effect of hydrodynamic cavitation.

Cavitation, especially hydrodynamical cavitation, causes disruption of activated sludge foam microorganism cells, therefore releasing an organic substance into solution (liquid phase/supernatant). These phenomena can be conventionally quantified and measured by commonly used COD test. Figure 10 shows measured COD value of sludge supernatant as a function of disintegration time $(t)$.

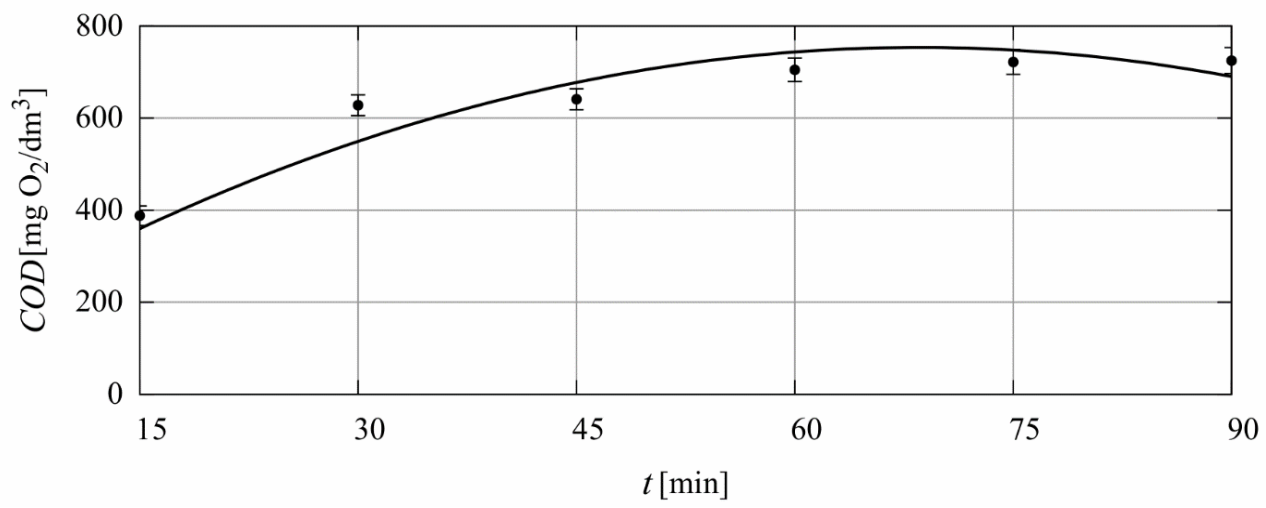

Fig. 10. Measured chemical oxygen demand (COD) as a function of disintegration time

Magnitude of COD is strictly related to the time of cavitational disintegration. After first 15 minutes of disintegration, there was observed an increase of COD value from 68 to $388 \mathrm{mg} / \mathrm{dm}^{3}$, and further increase, up to $628 \mathrm{mg} / \mathrm{dm}^{3}, 15$ minutes later. Probably, rate of change is the parameter that better facilitates evaluation of disintegration time (Fig. 11).

As we can see from Figure 11, the rate of COD achieves level of $21.3 \mathrm{mg} \mathrm{O} / \mathrm{dm}^{3} \cdot \mathrm{min}$ after first 15 minutes and successfully diminish. As we may expect, the Müller's disintegration degree $\mathrm{DD}_{\mathrm{M}}$ calculated accordingly from equation (11) also increases with the time of disintegration (Fig. 12).

We can observe a significant increase of the degree of disintegration in the first 30 minutes of experiment. Obtained $\mathrm{DD}_{\mathrm{M}}$ was here $50 \%$, and was continuously increasing till that moment. Further prolongation of the process may increase the COD and $\mathrm{DD}_{\mathrm{M}}$ but the rate diminish with time, and it becomes economically unprofitable. 


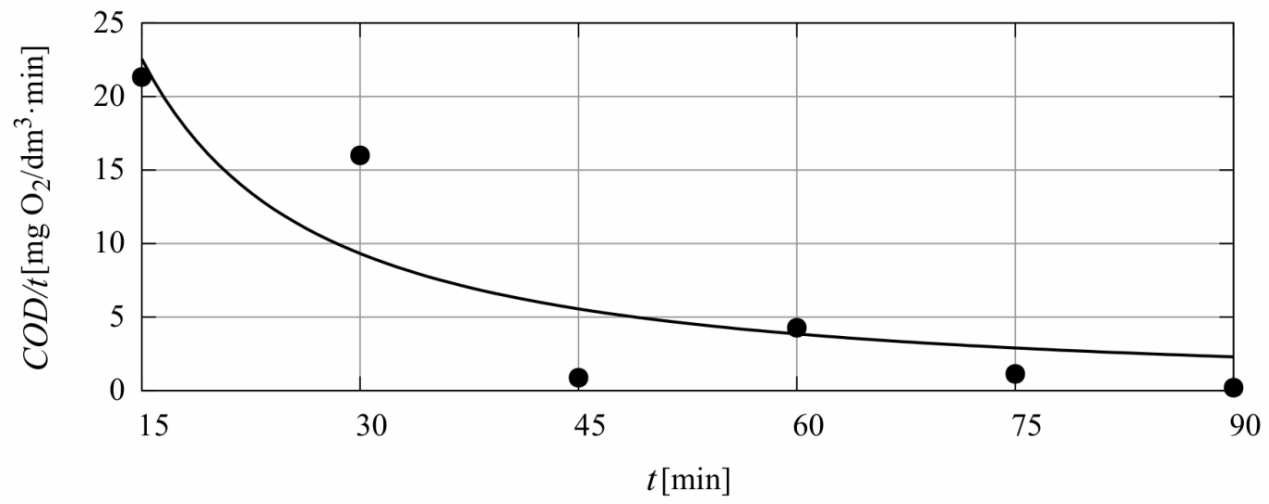

Fig. 11. Rate of change of oxygen demand as a function disintegration time

Changes of $\mathrm{COD}$ and $\mathrm{DD}_{\mathrm{M}}$ unequivocally point out strong hydrodynamic cavitation effect on activated sludge foam flocs and microorganisms.

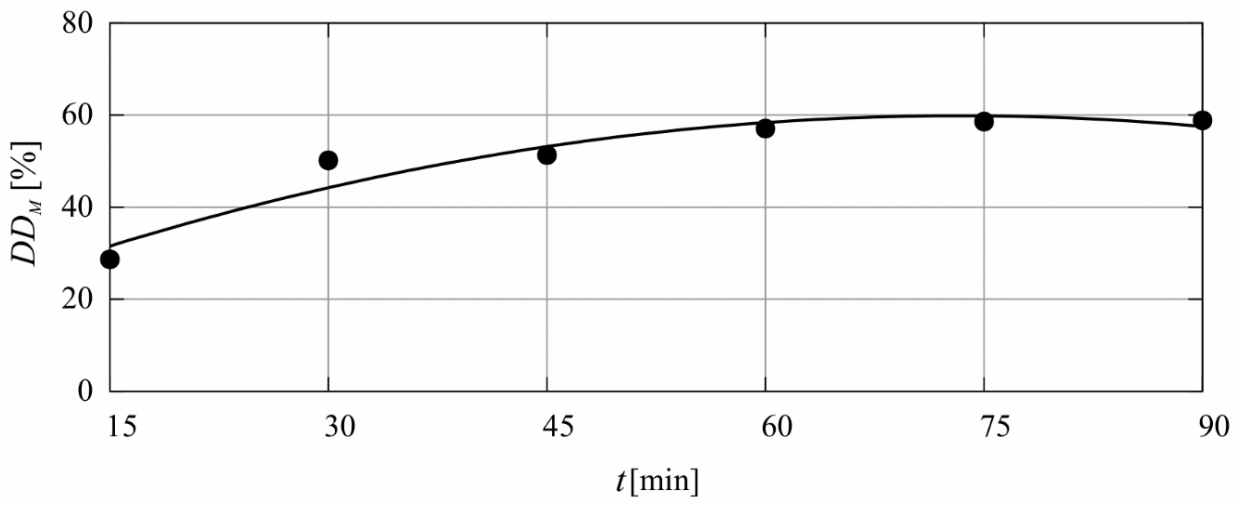

Fig. 12. Disintegration degree as a function of time

\section{Disintegration influence on biogas efficiency}

Anaerobic digestion technology is commonly used for the treatment of sewage sludge. However, this process is very slow and expensive, with big demand reactors volumes and retention times. Hence, many attempts and efforts have been undertaken towards improving its efficiency by thermal, chemical, or mechanical pre-treatments methods. One of the very promising alternatives is cavitational disintegration, previously through sonification and recently - more energy efficient and up-scalable - hydrodynamic cavitation.

Hydrodynamic disintegration accelerates the biological degradation of sludge. The released cell liquid contains components, which can be easily assimilated. The released organic substances (expressed here as COD value) as the effect of foam disintegration, leads to a substantial increase of biogas production in the process of anaerobic sludge digestion (Fig. 13). 


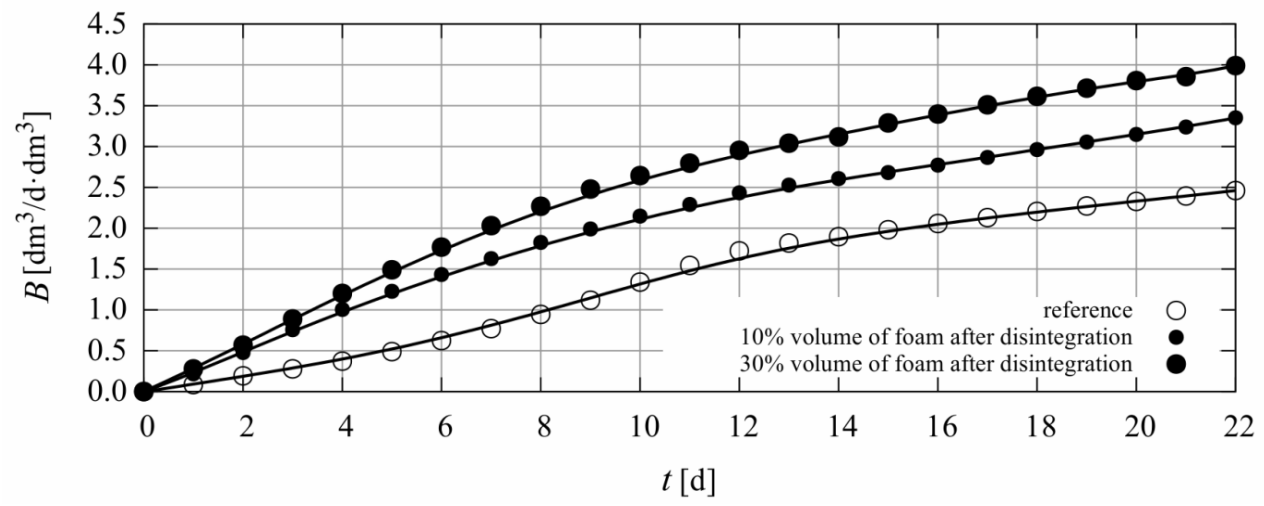

Fig. 13. Influence of volume fraction of disintegrated foam on rate of biogas production

Rate of biogas production is a self-evident and the final measure of the effectiveness of the digestion process. Significantly higher amounts of biogas were produced in the fermenters fed with disintegrated activated sludge foam. The gas production during the sludge digestion depends on volatile solids concentration, the degree of disintegration (expressed as COD), and fermentation time. Volatile solids of foam content ranged from 66 to $68 \%$. Small-scale mesophilic fermentation trials was performed. After addition of 10 and $30 \%$ of disintegrated activated sludge foam to fermenters the production of biogas increased almost 84 and $95 \%$, respectively. This is an indication that the addition of cavitational disintegrated activated sludge foam to mesophilic fermentation can cause significant improvement of this process.

Obviously, the organic matter transferred by hydrodynamic treatment from the activated sludge foam solids into the liquid phase was readily biodegradable. The break-up of cells walls of the foam bacteria limits the degradation process but by applying hydrodynamic disruption of cells, occurs in minutes instead of days. The intracellular and extracellular components are set free and are immediately available for biological degradation, which leads to an acceleration of the anaerobic process.

\section{Conclusions}

1. Properly implemented Venturi effect (for diameter ratios of designed nozzle $\beta=d_{0} / d_{1}=0.30$ and cavitation number $\sigma=0.245$ ) caused effective disintegration which has a significant impact on the speed of fermentation and biogas production.

2. After only 30 minutes of applied pre-treatment, chemical oxygen demand increased by 8.63 times and Müller's disintegration degree was $50 \%$.

3. Adding 10 and $30 \%$ of the volume of disintegrated foam, increased production of biogas by almost 84 and $95 \%$, respectively. This is an indication that the addition of cavitational disintegrated foam in mesophilic anaerobic digestion can cause significant improvement of this process. 


\section{Acknowledgements}

This work was supported by the EU ROUTES project (Contract No 265156, FP7 2007-2013, THEME [ENV.2010.3.1.1-2] Innovative system solutions for municipal sludge treatment and management).

\section{References}

[1] Müller J. Disintegration as key-step in sewage sludge treatment. Water Sci Technol. 2000;41:123-139.

[2] Wang F, Lu S, Ji M. Ultrason Sonochem. 2006;13:334-338. DOI: 10.1016/j.ultsonch.2005.04.008.

[3] Panico JA, Esposito G, Pirozzi F, Piet NL, Lens PNL. Appl Energy. 2014;123:143-156. DOI: 10.1016/j.apenergy.2014.02.035.

[4] Suschka J, Machnicka A, Grübel K. Arch Environ Prot. 2007;33:55-65.

[5] Grübel K, Machnicka A, Suschka J. Ecol Chem Eng S. 2009;16:359-367. www.tchie.uni.opole.pl/freeECE/S_16_3/GrubelMachnicka_16(3).pdf.

[6] Vichare NP, Gogate PR, Pandit AB. Chem Eng Technol. 2000;23:683-690. DOI: 10.1002/1521-4125(200008)23:8<683.

[7] Kumar PS, Pandit AB. Chem Eng Technol. 1999;22:1017-1027. DOI: 10.1002/(SICI)1521-4125(199912)22:12<1017.

[8] Kumar PS, Kumar M S, Pandit AB. Chem Eng Sci. 2000;55:1633-1639. DOI: 10.1016/S0009-2509(99)00435-2.

[9] Karassik IJ, Messina JP, Cooper P, Heald ChC. Pump Handbook. 4th ed. New York: McGraw-Hill; 2008.

[10] Landau LD, Lifshitz EM. Course of Theoretical Physics. Fluid Mechanics. 2nd ed. Oxford: Elsevier; 2010.

[11] Brennen ChE. Fundamentals of Multiphase Flow. New York: Cambridge University Press; 2005.

[12] Brennen ChE. Cavitation and Bubble Dynamics. New York: Oxford University Press; 1995.

[13] Gogate PR, Pandit AB. Ultrason Sonochem. 2005;12:21-27. DOI: 10.1016/j.ultsonch.2004.03.007.

[14] Arrojo S, Benito Y. Ultrason Sonochem. 2008;15:203-211. DOI: 10.1016/j.ultsonch.2007.03.007.

[15] Park SH, Suh HK, Lee CS. Energy Fuels. 2008;22:605-613. DOI: 10.1021/ef7003305.

[16] Sou A, Hosokawa S, Tomiyama A. Int J Heat Mass Transfer. 2007;50:3575-3582. DOI: 10.1016/j.ijheatmasstransfer.2006.12.033.

[17] Bird RB, Stewart WE, Lightfoot EN. Transport Phenomena. 2nd ed. New York: John Wiley\&Sons; 2002.

[18] Chung TJ. Computational Fluid Dynamics. Cambridge: Cambridge University Press; 2002.

[19] Drikakis D, Geurts BJ. Turbulent Flow Computation. New York: Kluwer Academic Publishers; 2004.

[20] Mohammadi B, Pironneau O. Analysis of the K-epsilon Turbulence Model. Chichester: John Wiley\&Sons; 1994.

[21] Barre S, Rolland J, Boitel G, Goncalves E, Patella RF. Eur J Mech B/Fluids. 2009;28:444-464. DOI: 10.1016/j.euromechflu.2008.09.001.

[22] Wanga G, Senocakb I, Shyyb W, Ikohagic T, Cao S. Prog Aero Sci. 2001;37:551-581. DOI: 10.1016/S0376-0421(01)00014-8.

[23] Rice EW, Baird RB, Eaton AD, Clesceri LS. Standard Methods for the Examination of Water and Wastewater. 22nd ed. Washington: American Public Health Association; 2012. 


\title{
ROZWAŻANIA NAD WPŁYWEM EFEKTU VENTURIEGO NA FERMENTACJE MEZOFILOWA
}

\author{
${ }^{1}$ Wydział Inżynierii Materiałów, Budownictwa i Środowiska \\ Akademia Techniczno-Humanistyczna w Bielsku-Białej \\ ${ }^{2}$ Wydział Budowy Maszyn i Informatyki, Akademia Techniczno-Humanistyczna w Bielsku-Białej
}

\begin{abstract}
Abstrakt: Kawitacja hydrodynamiczna będąca efektem Venturiego jest jednym z obiecujących sposobów wstępnej obróbki osadów ściekowych. Badania przeprowadzono w celu wykazania wpływu kawitacji hydrodynamicznej na proces dezintegracji piany osadu czynnego i fermentacji mezofilowej. Kawitacja została wygenerowana $\mathrm{w}$ standardowej zwężce Venturiego o stosunku średnicy $\beta=d_{0} / d_{1}=0,30$, pracującej przy $\sigma=0,249$. Szczegółowa analiza Computational Fluid Design (CFD) została przedstawiona w klasie $k$ - $\in$ modelu przepływu wewnętrznego. Uzyskane wyniki analiz potwierdzają efekt silnej destrukcji komórek mikroorganizmów i uwalniania substancji organicznej do fazy płynnej. Po zastosowanej zaledwie 30-minutowej obróbce wstępnej chemiczne zapotrzebowanie tlenu wzrosło 8,63 razy, podczas gdy stopień dezintegracji Müllera wyniósł $50 \%$. Przeprowadzone prace dotyczące fermentacji mezofilowej potwierdziły znaczną poprawę produkcji biogazu.
\end{abstract}

Słowa kluczowe: kawitacja hydrodynamiczna, efekt Venturiego, piana osadu czynnego, fermentacja mezofilowa 